\title{
CHEMICAL FIXATION OF CHROMIUM BEARING DUMP MATERIAL
}

\author{
Ramachandran R. ${ }^{1}$ and Kanakasabi $\mathbf{R}^{2}$ \\ ${ }^{1}$ Member Secretary, Tamilnadu Pollution Control Board, Chennai. \\ ${ }^{2}$ Professor, Department of Civil Engineering, Annamalai University, Chidambaram
}

\section{INTRODUCTION}

Sodium Bichromate and Basic Chromium Sulphate were manufactured in a plant in Tamilnadu. During the manufacture, solid waste containing mainly Calcium chromate was generated. The solid waste without any treatment was piled within the plant premises. The solid waste generation was about 30 MT per day. It was estimated that approximately about 1.5 to 2.00 lakh tones of solid waste are accumulated. Assuming a density of 1.5 $\mathrm{gm} / \mathrm{cc}$, the volume was computed to be 1.0 lakh $\mathrm{m}^{3}$. As the dump material is spread over a large area, samples were collected at four different locations and at different depths viz., $0.0 \mathrm{~m}, 0.3 \mathrm{~m}, 0.6 \mathrm{~m}$, and $0.9 \mathrm{~m}$. The characteristics of solid waste are given in Table 1 . The total chromium varies from $8716 \mathrm{mg} / \mathrm{kg}$ to $16930 \mathrm{mg} / \mathrm{kg}$, while the hexavalent chromium ranged between $46 \mathrm{mg} / \mathrm{kg}$ and $173 \mathrm{mg} / \mathrm{kg}$. It is observed that the chromium concentration is more at the deeper depth i.e at $0.9 \mathrm{~m}$ and less at the top open face. This indicates that the chromium has leached from the top surface traveled into inner surface. The dump material Chromium bearing waste is categorized as hazardous waste as per Hazardous Waste (Management and Handling) amended Rules 2003. In general, the solid waste is of inorganic type. The waste is alkaline type due to the presence of high concentration of Calcium and $\mathrm{pH}$. The Sodium Chromate is highly water-soluble while the solubility of Total Chromate (as $\mathrm{Cr}^{2} \mathrm{O}^{3}$ ) is very low. There have been reports that the wells in nearby area have been impacted due to leachate generated from the dumps. It was proposed to dispose the dump materials in secure landfill to be established within the plant premises. The plant stopped its production in the year 1995. According to the Guidelines of Central Pollution Control Board permissible limits for heavy metals have been prescribed. The chromium concentration in water leaching test is 5 $\mathrm{mg} / \mathrm{L}$. As the concentration of chromium is about $108 \mathrm{mg} / \mathrm{L}$ in water leaching test, the dump material cannot be disposed directly into landfill. The dump material has to be subjected to solidification method to convert into nonleaching mass and then only can be disposed into landfill. This paper details on the Phase I of the studies carried out on solidification and stabilization of chromium bearing dump material.

\section{Solidification and Stabilization}

It is proposed to remove the dump material and dispose into secure landfill. The chromium concentration in water leaching test is $105 \mathrm{mg} / \mathrm{L}$ as against the permissible concentration of $5 \mathrm{mg} / \mathrm{L}$ for disposal into landfill as per Central Pollution Control Board criteria. Hence the dump material has to be subjected to solidification and stabilization as pretreatment for landfill.

Table 1. Characteristics of Dump Material

\begin{tabular}{|c|c|c|c|c|}
\hline \multirow{2}{*}{ Parameter } & \multicolumn{4}{|c|}{ Location } \\
\cline { 2 - 5 } & 1 & 2 & 3 & 4 \\
\hline $\mathrm{Co}$ & 56 & 63 & 66 & 72 \\
\hline $\mathrm{Tri} \mathrm{Cr}$ & 8716 & 8867 & 1630 & 10136 \\
\hline $\mathrm{Hexa} \mathrm{Cr}$ & 57 & 46 & 173 & 82 \\
\hline $\mathrm{Cu}$ & $\mathrm{SOL}$ & $\mathrm{SOL}$ & $\mathrm{SOL}$ & 1.3 \\
\hline $\mathrm{Fe}$ & 27003 & 30540 & 34084 & 24138 \\
\hline $\mathrm{Mg}$ & 16446 & 1481 & 20561 & 21613 \\
\hline $\mathrm{Mn}$ & 615 & 72 & 817 & 819 \\
\hline $\mathrm{Ni}$ & 290 & 331 & 33 & 314 \\
\hline $\mathrm{Pb}$ & $\mathrm{SOL}$ & 3.3 & 2.5 & 6.2 \\
\hline $\mathrm{Zn}$ & 102 & 136 & 196 & 189 \\
\hline
\end{tabular}

Notel : All con.are expressed in $\mathrm{mg} / \mathrm{kg}$

The main objective of immobilization technology is to convert the hazardous and toxic wastes into an inert, physically stable mass, with very low leachability and sufficient strength to allow for land filling or land reclamation.

Immobilization (or chemical stabilization) is a process in which the waste is converted to a more chemically stable or more insoluble or immobile form.

Solidification or cementation is a process in which the waste is converted to an insoluble rock like material by mixing with suitable material to form a solid product.

The use of solidication and stabilization (S/S) process can greatly reduce the effective concentration of waste disposed at a site and thus could be used to limit the amount of macro-encapsulation in specially designed cells of both inorganic (such as arsenic) and organic wastes (such as pesticides) that are contained in sealed drums. The cell is constructed within an appropriate containment landfill and is designed to minimize the potential leakage of waste from the cell. Macro-encapsulation of inorganic, always has an important role to play but it is preferable to incinerate organic rather than encapsulate them.

Solidification and stabilization of sludge uses additives to reduce the mobility of pollutants. In many cases, lime is added for stabilizing the waste. It has gained 
popularity in recent years following strict regulations on land disposal of waste classified as hazardous. $S / S$ is essentially a cost-effective disposal option as compared to landfill disposal for hazardous wastes. S/S typically involves easily available and inexpensive raw materials and simple technologies.

S/S of hazardous wastes through the application of cement, clayey soil, fly ash based binders has been applied to various types of wastes containing heavy metals. (Conners, 1990). This technology is reported to be cost effective and safe for heavy metals containing solid wastes (Valls and Vazques / 2002). A comprehensive review on S/S has been published by (Spence 1993 : Hills et. Al 1993) The fundamental physico-chemical aspects of S/S has been reported. (Moliah et,al. 1994). Palomo and Palacios (2003) have conducted detailed studies of S/S of chromium laden wastes using alkali-activated fly ash. Rossetti et.al. (2002) abstracted the optimization of S/S for wastes having $\mathrm{Cr}, \mathrm{Pb}, \mathrm{Zn}$, and $\mathrm{Li}$. Addition of activated carbon to the sludges containing $\mathrm{Cr}, \mathrm{Zn}, \mathrm{Pb}$, Cu etc., have improved the S/S as shown by the low concentration of heavy metals in TCLP (Chan et.al. 2000). The mechanical and leaching properties of $\mathrm{S} / \mathrm{S}$ for sludges containing $\mathrm{Cr}$, $\mathrm{Mn}, \mathrm{Pb}$ and Zinc was investigated in detail by Gervails and Ouki (2002). Wang and Vipulandan (2000) studie the leaching potential of chromium laden wastes using cement as binder. Swaminathan (1998) carried out exchaustive studies on S/S for leather tannery wastes containing trivalent chromium. In this study clayey soil was added as binder with leather waste containing chromium. Leaching of chromium was least. However, on heating to convert into conventional building brick, trivalent chromium got converted into hexavalent chromium and hence the chromium was present in the leachate. Most of the studies were based on trivalent chromium. In this study attempts are made to study the efficacy of $S / S$ for a waste containing both types of chromium.

Bench scale experiments were carried out to evaluate the efficacy of solidification and stabilization (S/S) method.

\section{Experimental Studies Details Admixture Selection}

The main purpose of the bench scale experimental studies is to evaluate the efficacy of the solidification and stabilization technique for the dump material. Among the various admixtures available cement mortar was considered. If clay is added to the waste, it has to be fired to convert into brick as is done in conventional brick making. Some studies reported earlier with the solid waste containing trivalent chromium that after firing, the trivalent chromium gets converted into hexavalent chromium. The insoluble chromium gets converted into leachable chromium. Further, the bricks contain greenish yellow patches making the bricks not acceptable. Hence clay was not considered. Cement mortar (cement and sand) is considered in this study.

\section{Mixing Ratio}

The mixing ratio of solid waste to admixture considered in this study is as under:

In each mixing proporation, six blocks were made. The blocks are made using a mould $(6 \mathrm{~cm} \times 6 \mathrm{~cm} \times 6 \mathrm{~cm})$. Approximate quantity of dump material and cement mortar was computed to make 6 blocks in each proportion. The approximate volume was measured taking about 10 to $15 \%$ as extra to meet any contingency arising during block making. These attempts are made to obtain a

\begin{tabular}{|c|c|c|}
\hline Mix No & $\begin{array}{c}\text { Volume of } \\
\text { dump material } \\
(\%)\end{array}$ & $\begin{array}{c}\text { Volume of } \\
\text { Cement } \\
(\%)\end{array}$ \\
\hline 1 & 50 & 50 \\
\hline 2 & 60 & 40 \\
\hline 3 & 70 & 30 \\
\hline 4 & 80 & 20 \\
\hline 7 & - & Control \\
\hline
\end{tabular}

Note: Mixing percent is in Volume basis

Homogeneous mix in each mixing proportion. The required quantity was measured and kept separately. The admixtures were mixed in volume basis keeping the different sludge ratio.

The cement mortar is of CM 1:3. This consists of 1 part of cement and 3 parts of sand by volume basis.

\section{Block making}

Initially the cement and sand are mixed in 1:3 ratio to get cement mortar. The cement used is of Portland cement. The required quantity of dump material and cement mortar for various proportions were piled. The cement mortar and solid waste for the required proportion were mixed and water was added gradually till consistency was achieved. After thorough mixing, it was kept for about 5 to 10 minutes. Blocks were made using the moulds and compacted. The block was removed from the mould and numbered for identification. The block was removed from the mould and numbered for indetification. The blocks were stacked (but not piled) in a shed.

The inner volume of block is $216 \mathrm{cc}$. This $216 \mathrm{cc}$ is after compaction. The actual volume of cement mortar and solid waste used is more than $216 \mathrm{cc}$. Actual volume of additives added per block is shown in Table 2 . 


\section{Curing Period}

The blocks have been kept in shed and cured. It took about 15 to 20 days to obtain maximum curing. It has been reported in literature! and from the experience of the consultant, the curing period should be around 21 to 28 days. As the sky was overcast during the study period, the curing period was fixed at 28 days. At the end of 28 days the blocks were sent for testing.

Table-2 : Actual Volume Added per Block

\begin{tabular}{|c|c|c|c|}
\hline Mix No & $\begin{array}{c}\text { Volume of } \\
\text { dump material } \\
(\mathrm{ml})\end{array}$ & $\begin{array}{c}\text { Volume of } \\
\text { Cement } \\
(\mathrm{ml})\end{array}$ & $\begin{array}{c}\text { Volume of } \\
\text { water } \\
(\mathrm{ml})\end{array}$ \\
\hline 1 & $125(70)$ & $125(253)$ & $100(100)$ \\
\hline 2 & $150(84)$ & $100(202)$ & $100(100)$ \\
\hline 3 & $175(98)$ & $75(151)$ & $100(100)$ \\
\hline 4 & $200(112)$ & $50(100)$ & $100(100)$ \\
\hline 7 & - & $250506)$ & $100(100)$ \\
\hline
\end{tabular}

Note: Values in brackets are in gm.

\section{Result and Discussion}

After curing period of 28 days, $\mathrm{S} / \mathrm{S}$ concrete blocks were tested for chemical leaching potential through TCLP test.

The most important criteria to evaluate the $S / S$ are to test for the leaching potential. Originally, the $S / S$ blocks were immersed in water for 90 days and analyze the water at periodical interval. Due to long time involved, US EPA has modified the test procedure and now Extraction Procedure (EP) Toxicity or TCLP has been followed. This is also in conformity with the Guidelines of CPCB (Guidelines for proper Functioning \& Upkeep of Disposal Sites-October 2004).

The block in each mixing ratio was powdered and mixed thoroughly to get a representative sample.

The important pollutant present in the sludge is chromium. Other heavy metals such as nickel, lead and cadmium are in low concentration. However, all heavy metals were considered as parameters for evaluating the leaching potential of solidified mass. The data are presented in Table-3.
Table-3: Heavy metals in TCLP test of solidified block

\begin{tabular}{|c|c|c|c|c|c|}
\hline Parameter & Alt 1 & Alt2 & Alt 3 & Alt 4 & Control \\
\hline Ratio & $50: 50$ & $60: 40$ & $70: 30$ & $80: 20$ & - \\
\hline $\mathrm{Cr}$ & 57.6 & 62.15 & 64.34 & 70.17 & 2.36 \\
\hline $\mathrm{Cr6}$ & 40.33 & 43.28 & 52.56 & 50.25 & 0.05 \\
\hline $\mathrm{Ni}$ & $<0.5$ & $<0.5$ & $<0.5$ & $<0.5$ & $<0.5$ \\
\hline $\mathrm{Zn}$ & $<0.5$ & 1.42 & 1.2 & 2.4 & $<0.5$ \\
\hline $\mathrm{Pb}$ & 0.01 & 0.11 & 0.9 & 0.09 & 0.05 \\
\hline $\mathrm{Cd}$ & $<0.01$ & $<0.01$ & $<0.01$ & $<0.01$ & $<0.01$ \\
\hline
\end{tabular}

All values expressed in $\mathrm{mg} / \mathrm{L}$

In general, the heavy metal in TCLP extract increases marginally with the increase of dump material : admixture mixing ratios. The chromium was observed to be $57.6 \mathrm{mg} / \mathrm{L}$ in 50:50 mix (alternative 1) and was increased to $70.17 \mathrm{mg} / \mathrm{L}$ at 80:20 mix ratio alternative 4). The hexavalent chromium varied from $40.33 \mathrm{mg} / \mathrm{L}$ to 50.25 $\mathrm{mg} / \mathrm{L}$.

It can be seen that the chrofum concentration even after $S / S$ is high. Even solidification and Stabilization process is not effective at lower mixing ratio of 50:50. This is probably due to the presence of hexavalent chromium. The concentration even after S/S does not comply with the threshold limit prescribed by CPCB. It is therefore concluded tht the dump material has to be subjected to treatment to convert the hexavalent chromium to trivalent chromium to improve the efficacy of $S / S$ and to comply with the prescribed limit of CPCB. Further studies in this direction is in progress.

\section{CONCLUSION}

Studies were carried out to evaluate the efficacy of S/S process for bpretreating the chromium bearing dump material prior to landfilling. Due to the high presence of chromium, $S / S$ is observed to be non-effective. It is therefore considered to pretreat the dump material to convert into trivalent chromium and then subject to $S / S$ process.

\section{REFERENCES}

[1] Chan, Y.M., Agamuthu, P., Mahalingam, R. (2000). Solidification / Stabilization Asbestos Waste from an Automobile Brake Manufacturing Facility using Cement., J. Hazard. Mter. B.77, 209-226.

[2] Connel../J.R. (1990), Chemical Fixation and Solidication of Hazardous wastes, Van Nostrand Reinhold, NY 
[3] Gervais, C., and Ouki, S.K., (2002). Performance Study of Cementitious Systems Containing Zeolite and Silica Fumes: Effect of Four Metal Nitrates on the Setting Time, Strength, and Leaching Characteristics., J. Hazard. Mater. B93, 187 - 200 Hills, C.o., Sollars, C.J. Perry, R. (1993). Ordinary Portland Cement Based Solidification of Toxic Wastes : The Role of OPC Reviewed, Cem. Concr. Res. 23(1), 196-212.

[4] Mollah, M.Y., Tsai, Y.N., Hess, T.R.' Cocke,o.L. (1993). Chemical and Physical Effects of Sodium Lignosulfonate Superplasticizer on the hydration of Portland Cement and Solidication / Stabilization Consequences, Cem.Concr. Res. 25(3), 671-682.

[5] Palomo, A., and Palacios, M. (2003). AlkaliActiviated Cementitious Materials :

[6] Alternative Matrices for the Immobilization of Hazardous Wastes Part II. Stabilization of Chroium and Lead, Cem.Concr. Res. 33, 289-295.

[7] Rossetti A.V., oi Palma L., Medici F.(2002). Assessment of the Leaching of Metallic Elements in the Technology of solidification in Aqueous Solution, Waste Manage. 22(6), 605-610.
[8] Spence, R.D (19930. Chemistry and Micro.structure of Solidified Wasteforms, Lewis Publishers, Boca Raton, FL., USA

[9] Swaminathan R.and Valentine Post. (1998). Solidification of Tannery Sludge. Report Prepared for RePO, UNIDO.

[10] Valls, S., Vazquez,E. (2002). Leaching properties of stabilized/solidified cement admixtures - sewage sludges systems, Waste Management, 22, 37-45.

[11] Wang, S., Vipulandan, C. (2000). Solidification / Stabilization of $\mathrm{Cr}(\mathrm{VI})$ with Cement Leachability and XRoAnalyses, Cem. Concr. Res. 30, 385-389.

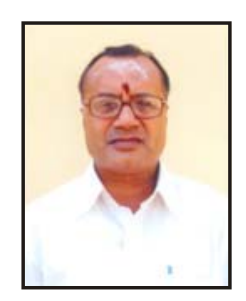

R. Ramachandran Member Secretary of Tamilnadu Pollution Control Board, Chennai is having 25 years of experience in Tamilnadu Pollution Control Board on enforcement of environmental laws in industries monitoring activities, water pollution control measures, air pollution control measures and Hazardous waste, Solid Waste, Biomedical waste management system and issue of consent mechanism to the industries in accordance with the environmental laws. 